\title{
Effect of N, K and S on the Yield and Storability of Transplanted Onion (Allium cepa L.) in the Hilly Region
}

\author{
S. N. MOZUMder ${ }^{1 *}$, M. MonirUZzAMAN ${ }^{2}$ AND G. M. A. HALiM ${ }^{3}$ \\ ${ }^{1}$ Hill Agricultural Research Station, Ramgarh, Khagrachhari Hill District, Bangladesh \\ ${ }^{2}$ Agricultural Research Station, Raikhali, Chandraghona, Rangamati Hill District, Bangladesh \\ ${ }^{3}$ Horticulture Research Station, Centre, BARI, Joydebpur, Gazipur, Bangladesh
}

\begin{abstract}
An experiment was conducted during October 2003 to February 2005 at the Agricultural Research Station, Raikhali, Rangamati to investigate the effect of $N, K$ and $S$ on the yield and storability of transplanted onion (Allium cepa L.) in the hilly region. Fourteen combinations of treatments comprising $N\left(0,100,125,150\right.$ and $175 \mathrm{~kg} / \mathrm{ha}$.),$K_{2} \mathrm{O}(0,75,100,125,150$ and $175 \mathrm{~kg} / \mathrm{ha}$.) and $\mathrm{S}(0$, 12, 24 and $36 \mathrm{~kg} / \mathrm{ha}$.) with a common dose of decomposed cowdung @ $10 \mathrm{t} / \mathrm{ha}$ and $75 \mathrm{~kg} \mathrm{P}_{2} \mathrm{O}_{5}$ were used. Application N, K and S significantly increased yield and yield attributes. The maximum plant height $(41.8 \mathrm{~cm})$, length of bulb $(4.49 \mathrm{~cm})$ and diameter of bulb $(3.85 \mathrm{~cm})$, single bulb weight $(41.4 \mathrm{~g} / \mathrm{ha})$, fresh yield (10.33 t/ha) and gross return (Tk.1,23,960/ha) were obtained with the treatment $N_{125} K_{175} S_{24} \mathrm{~kg} / \mathrm{ha}$. The maximum number of leaves (7.67/plant) were obtained from $N_{175} K_{100} S_{24}$, net return (Tk. 91,322/ha) from $N_{125} K_{150} S_{24}$ and benefit cost ratio (3.89) was obtained from the treatment $N_{150} K_{100} S_{24} \mathrm{~kg} / \mathrm{ha}$. Excessive nitrogen caused rapid deterioration and weight loss of bulbs during storage at ambient temperature.
\end{abstract}

Key words: Onion, seedling, storability, hilly region.

\section{INTRODUCTION}

Onion (Allium cepa L.) is one of the most important spices and bulb crop. Recently, it is considered as a major cash crop in the western part of Bangladesh. It occupies a major part in respect to area and production of spice crop in Bangladesh. But the production is very much insufficient (0.13 million ton) compared to demand (1.2 million ton/annum) (Anon. 2005). This is due to the low yield and cultivation is more or less confined only in the western part of the country. In some other parts of the country, onions are cultivated in small scale and mostly bulb to bulb production. But the onions produced by planting smaller bulbs in such way are not able to store for longer period in ambient condition. For year round consumption seed to bulb or seedling to bulb is better. The national average yield of onion is very low (3.94 t/ha) compared to research organization (12-16 t/ha) or international yield (17.27 t/ha) (Anon. 2000, 2005). The low yield is due to lack of high yielding variety and use of poor management practices. Fertilizer management is one of the important management factors that may contribute much to the onion yield. Nitrogen, potassium and sulphur are important nutrient element that play important role on bulb formation, elongation, skin color development and pungency of onion (Bose and Som, 1986; Vachhani and Patel. 1993). Moreover, $\mathrm{N}$ can easily volatilize and leached out of root zones and fertilization may be needed for high yields (Brewster, 1994; Marschner, 1995). The K requirement of onion plants increases with yield as

* Corresponding author: D-4/5, BSMRAU, Salna, Gazipur-1706, Cell: 01711 901497, Email: shailenbari95@yahoo.com

(C) 2006 School of Agriculture and Rural Development, Bangladesh Open University, All rights reserved. 


\section{S.N. Mozumder et al.}

its functions are linked to photosynthesis (Greenwood \& Stone, 1998). The present experiment was therefore, designed with an emphasis to nitrogen, potassium and sulphur application since vegetative growth and bulb production is important for this crop. However, this study was undertaken to find out the optimum doses of $\mathrm{N}, \mathrm{K}$ and $\mathrm{S}$ for higher yield and storability of onion and to observe the possibility of onion cultivation using transplanting system in the eastern hilly areas of Bangladesh.

\section{MATERIALS AND METHODS}

The present experiment was conducted during October 2003 to February 2005 at the Agricultural Research Station, Raikhali, Rangamati Bangladesh. The experimental field belonged to AEZ 29 and the soil was Piedmont plain having medium loamy to moderately fine texture (sandy clay loam). The soils had $5.4 \mathrm{pH}$ and $1.48 \%$ organic matter. The total $\mathrm{N}$, available $\mathrm{P}, \mathrm{S}$ and $\mathrm{K}$ were $0.078 \%, 8.0 \mu \mathrm{g} / \mathrm{g}, 6.7 \mu \mathrm{g} / \mathrm{g}$ and $0.17 \mathrm{meq} / 100 \mathrm{~g}$ soil. Seeds of Taherpuri cultivar were sown in beds on 10 October and seedlings were transplanted on 15 November, 2003. Fourteen combinations (as sown in table 1) of treatments comprising $\mathrm{N}\left(0,100,125,150\right.$ and $175 \mathrm{~kg} / \mathrm{ha}$.), $\mathrm{K}_{2} \mathrm{O}(0,75,100,125,150$ and $175 \mathrm{~kg} / \mathrm{ha}$.) and $\mathrm{S}(0,12$, 24 and $36 \mathrm{~kg} / \mathrm{ha}$.) with a common dose of $75 \mathrm{~kg} / \mathrm{ha} \mathrm{P}_{2} \mathrm{O}_{5}$ and decomposed cowdung $10 \mathrm{t} / \mathrm{ha}$ were designed following North Carolina State University (Anonymous, 1969) used for this trial. The experiment was laid out in a RCB design with three replications. The bed size was $4 \times 2.5 \mathrm{~m}$ accommodating 500 plants per plot with $20 \times 10 \mathrm{~cm}$ spacing. The total amounts of cowdung, TSP (P), Gypsum (S), one third of MP $(K)$ and urea $(N)$ were applied during final land preparation and the rest of the urea and MP were applied in two equal installments at 25 and 45 days after transplanting. Irrigation, weeding, mulching and other cultural practices were done as and when necessary. Harvesting was done when most of the necks are fallen. After lifting of bulbs, pseudostems and leaves were removed and bulbs were dried in shade for 3 days. Data on plant height, number of leaves per plant, bulb size and single bulb weight were taken from 20 plants from each plot. The total yield was calculated from the weight of bulbs of each plot. One kilograms of bulb from each plot was kept for storage in aerated plastic tray in the normal temperature $\left(24-32^{\circ} \mathrm{C}\right)$ condition and weight and number of the stored onion bulb was recorded at two months intervals. The recorded data were analyzed by MSTAT program and the treatment means were separated By DMRT for interpretation of the results. Economic calculation was done on the basis of local market price of inputs (fertilizers, seeds, labor etc.) and output (Tk. 12/kg bulb). The polynomial regression analysis was done and optimum dose of nutrient elements for maximum seed yield and economic rate of inputs were calculated from simple polynomial regression equations $i$ e. $Y=\alpha+\beta_{1} X+\beta_{2} X^{2}$ (Zaman et al. 1982). Here $x$ is the independent variable (input) and $Y$ is the dependent variable (yield). The optimum dose of nutrient element for maximum yield is $X=-\beta_{1} / 2 \beta_{2}$ and economic dose were $X_{e}=X-\left({ }^{P x} / P_{y}\right) / 2 \beta_{2}$. Here $P_{x}$ is the price of input and $P_{y}$ is the price of the products.

Table1. Effect of $\mathrm{N}, \mathrm{K}$ and $\mathrm{S}$ on the growth and yield attributes of onion in the hilly region.

\begin{tabular}{lccccc}
\hline Treatments & $\begin{array}{c}\text { Plant height } \\
\text { (cm) }\end{array}$ & $\begin{array}{c}\text { Number of } \\
\text { leaves /plant }\end{array}$ & $\begin{array}{c}\text { Length of } \\
\text { bulb (cm) }\end{array}$ & $\begin{array}{c}\text { Diameter of } \\
\text { bulb (cm) }\end{array}$ & $\begin{array}{c}\text { Wt. of single } \\
\text { bulb (g) }\end{array}$ \\
\hline $\mathrm{N}_{0} \mathrm{~K}_{0} \mathrm{~S}_{0}\left(\mathrm{~T}_{1}\right)$ & $32.4 \mathrm{bc}$ & $5.20 \mathrm{~d}$ & $3.47 \mathrm{bc}$ & $2.87 \mathrm{e}$ & $16.7 \mathrm{e}$ \\
$\mathrm{N}_{0} \mathrm{~K}_{100} \mathrm{~S}_{24}\left(\mathrm{~T}_{2}\right)$ & $37.9 \mathrm{ab}$ & $5.60 \mathrm{bcd}$ & $3.88 \mathrm{ab}$ & $3.27 \mathrm{~b}-\mathrm{e}$ & $22.0 \mathrm{de}$ \\
$\mathrm{N}_{100} \mathrm{~K}_{100} \mathrm{~S}_{24}\left(\mathrm{~T}_{3}\right)$ & $40.2 \mathrm{a}$ & $6.20 \mathrm{a}-\mathrm{d}$ & $4.20 \mathrm{a}$ & $3.38 \mathrm{a}-\mathrm{d}$ & $28.0 \mathrm{~cd}$ \\
$\mathrm{~N}_{125} \mathrm{~K}_{100} \mathrm{~S}_{24}\left(\mathrm{~T}_{4}\right)$ & $40.2 \mathrm{a}$ & $6.67 \mathrm{a}-\mathrm{d}$ & $4.29 \mathrm{a}$ & $3.51 \mathrm{a}-\mathrm{d}$ & $35.3 \mathrm{abc}$ \\
$\mathrm{N}_{150} \mathrm{~K}_{100} \mathrm{~S}_{24}\left(\mathrm{~T}_{5}\right)$ & $40.3 \mathrm{a}$ & $7.40 \mathrm{a}$ & $4.41 \mathrm{a}$ & $3.72 \mathrm{abc}$ & $40.7 \mathrm{a}$ \\
$\mathrm{N}_{175} \mathrm{~K}_{100} \mathrm{~S}_{24}\left(\mathrm{~T}_{6}\right)$ & $41.1 \mathrm{a}$ & $7.67 \mathrm{a}$ & $4.43 \mathrm{a}$ & $3.79 \mathrm{ab}$ & $41.3 \mathrm{a}$ \\
$\mathrm{N}_{125} \mathrm{~K}_{0} \mathrm{~S}_{24}\left(\mathrm{~T}_{7}\right)$ & $29.4 \mathrm{c}$ & $6.27 \mathrm{a}-\mathrm{d}$ & $3.18 \mathrm{c}$ & $3.01 \mathrm{de}$ & $22.7 \mathrm{de}$ \\
$\mathrm{N}_{125} \mathrm{~K}_{75} \mathrm{~S}_{24}\left(\mathrm{~T}_{8}\right)$ & $35.4 \mathrm{abc}$ & $6.40 \mathrm{a}-\mathrm{d}$ & $3.77 \mathrm{ab}$ & $3.49 \mathrm{a}-\mathrm{d}$ & $31.0 \mathrm{bc}$ \\
$\mathrm{N}_{125} \mathrm{~K}_{125} \mathrm{~S}_{24}\left(\mathrm{~T}_{9}\right)$ & $40.2 \mathrm{a}$ & $7.00 \mathrm{abc}$ & $4.39 \mathrm{bc}$ & $3.67 \mathrm{abc}$ & $36.8 \mathrm{ab}$ \\
$\mathrm{N}_{125} \mathrm{~K}_{150} \mathrm{~S}_{24}\left(\mathrm{~T}_{10}\right)$ & $41.3 \mathrm{a}$ & $7.40 \mathrm{a}$ & $4.39 \mathrm{bc}$ & $3.76 \mathrm{abc}$ & $40.0 \mathrm{a}$ \\
$\mathrm{N}_{125} \mathrm{~K}_{175} \mathrm{~S}_{24}\left(\mathrm{~T}_{11}\right)$ & $41.8 \mathrm{a}$ & $7.60 \mathrm{a}$ & $4.49 \mathrm{bc}$ & $3.85 \mathrm{a}$ & $41.4 \mathrm{a}$ \\
$\mathrm{N}_{125} \mathrm{~K}_{100} \mathrm{~S}_{0}\left(\mathrm{~T}_{12}\right)$ & $31.3 \mathrm{bc}$ & $5.53 \mathrm{~cd}$ & $3.39 \mathrm{bc}$ & $2.79 \mathrm{e}$ & $32.0 \mathrm{bc}$ \\
$\mathrm{N}_{125} \mathrm{~K}_{100} \mathrm{~S}_{12}\left(\mathrm{~T}_{13}\right)$ & $35.1 \mathrm{abc}$ & $6.53 \mathrm{a}-\mathrm{d}$ & $3.73 \mathrm{~b}$ & $3.26 \mathrm{cde}$ & $36.0 \mathrm{ab}$ \\
$\mathrm{N}_{125} \mathrm{~K}_{100} \mathrm{~S}_{36}\left(\mathrm{~T}_{14}\right)$ & $38.6 \mathrm{ab}$ & $7.60 \mathrm{a}$ & $4.17 \mathrm{a}$ & $3.82 \mathrm{a}$ & $40.3 \mathrm{a}$ \\
\hline $\mathrm{CV} \%$ & 8.10 & 9.63 & 13.71 & 5.90 & 9.67 \\
$\mathrm{Sig}$ & $* *$ & $* *$ & $*$ & & $*$ \\
\hline
\end{tabular}




\section{RESULTS AND DISCUSSION}

Almost all yield attributes, yield and profitability were significantly affected with different doses of nitrogen, potassium and sulphur except the storability of onion.

Effect of nitrogen: Plant height, number of leaves/plant, length and diameter of bulb, single bulb weight and yield of bulb significantly increased with the increase of nitrogen fertilizer up to $150 \mathrm{~kg}$ $\mathrm{N} /$ ha $($ Table $1 \& 2\}$. The maximum plant height $(41.1 \mathrm{~cm})$ and number of leaves $(7.67 / \mathrm{plant})$ were obtained from $175 \mathrm{~kg}-\mathrm{N} / \mathrm{ha}$ which was similar with $150 \mathrm{~kg}, 125 \mathrm{~kg}$ and $100 \mathrm{~kg}-\mathrm{N} / \mathrm{ha}$. The minimum plant height $(37.9 \mathrm{~cm})$ and number of leaves (5.20/plant) were obtained from the control $(0 \mathrm{~kg}-\mathrm{N} / \mathrm{ha})$. Higher length of bulb $(4.41 \mathrm{~cm})$ and bulb diameter $(3.79 \mathrm{~cm})$ were obtained from $175 \mathrm{~kg}-\mathrm{N} / \mathrm{ha}$. The maximum single bulb weight $(41.3 \mathrm{~g})$ and bulb yield $(10.23 \mathrm{t} / \mathrm{ha})$ were obtained from the highest level (175 kg-N/ha) of nitrogen. This result was similar with the reports of Bose and Som (1986) that $\mathrm{N}$ application significantly increased onion yield. Nitrogen had a marked positive effect on fresh yield, gross return (GR), net return (NR) as well as benefit cost ratio (BCR) (Table 2). The higher GR (Tk.1,22,760/ha), NR (Tk. 91045/ha) was obtained from the highest level of N (175kg N/ha) while the maximum BCR (3.89) was found with $150 \mathrm{~kg}-\mathrm{N} / \mathrm{ha}$. Larger bulbs with higher yield of onion due to $\mathrm{N}$ application is likely as because nitrogen encourages cell elongation, above ground vegetative growth and to imparts dark green color of leaves (Brady, 1985). Figure-1 showed that the rate of yield increase was reduced after $150 \mathrm{~kg} / \mathrm{ha} \mathrm{N}$ application. From the polynomial regression analysis (Fig.1), nitrogen shows a strong positive correlation ( $R=0.9937)$ between $N$ application and bulb yield. The calculated optimum level of $\mathrm{N}$ from the regression equation for yield is $168 \mathrm{~kg}-\mathrm{N} / \mathrm{ha}$ and the most economic level is $165 \mathrm{~kg}-\mathrm{N} / \mathrm{ha}$. The overall condition of bulb showed similar trend of weight loss during storage and also number of rotten bulbs with different $\mathrm{N}$ levels (Fig 4 \& 5). This result supports the reports of Woldetsadik (2003) that nitrogen sources caused few and small differences in internal and external bulb quality. Fig 4 showed the gradual weight loss before and drastic after October. Slight rapid deterioration was observed in $T_{6}$ treatment when maximum N (175 kg/ha) was applied. Moreover, a higher risk of bulb storage losses was observed in N-fertilized plants (Singh \& Dankhar, 1991). Batal et al. (1994) also showed that high levels of nitrogen fertilization promote sprouting and decay of onions.

Table 2. Effect of $\mathrm{N}, \mathrm{K}$ and $\mathrm{S}$ on yield and profitability of onion.

\begin{tabular}{|c|c|c|c|c|c|}
\hline Treatments & Yield (t/ha) & $\begin{array}{c}\text { Gross return } \\
\text { (Tk/ha) }\end{array}$ & $\begin{array}{c}\text { Variable cost } \\
(\mathrm{Tk} / \mathrm{ha})\end{array}$ & $\begin{array}{c}\text { Net return } \\
\text { (Tk/ha) }\end{array}$ & $\begin{array}{l}\text { Benefit cost } \\
\text { ratio }\end{array}$ \\
\hline $\mathrm{N}_{0} \mathrm{~K}_{0} \mathrm{~S}_{0}$ & $5.23 e$ & $62760 \mathrm{e}$ & 26000 & $36760 d$ & $2.41 \mathrm{c}$ \\
\hline $\mathrm{N}_{0} \mathrm{~K}_{100} \mathrm{~S}_{24}$ & $6.73 e f$ & 80760ef & 29310 & $51450 \mathrm{bc}$ & $2.76 \mathrm{bc}$ \\
\hline $\mathrm{N}_{100} \mathrm{~K}_{100-} \mathrm{S}_{24}$ & 7.83b-e & 93960b-e & 30684 & $63276 b$ & $3.06 \mathrm{~b}$ \\
\hline $\mathrm{N}_{125} \mathrm{~K}_{100} \mathrm{~S}_{24}$ & $9.13 a b c$ & $109560 a b c$ & 31028 & $78532 a b$ & $3.83 a b$ \\
\hline $\mathrm{N}_{150} \mathrm{~K}_{100} \mathrm{~S}_{24}$ & $10.16 a$ & 121920a & 31371 & $90549 a$ & $3.89 a$ \\
\hline $\mathrm{N}_{175} \mathrm{~K}_{100} \mathrm{~S}_{24}$ & $10.23 a$ & $122760 a$ & 31715 & $91045 a$ & $3.87 a$ \\
\hline $\mathrm{N}_{125} \mathrm{~K}_{0} \mathrm{~S}_{24}$ & $6.17 \mathrm{ef}$ & 74040ef & 28528 & $45512 \mathrm{~cd}$ & $2.60 b c$ \\
\hline $\mathrm{N}_{125} \mathrm{~K}_{75} \mathrm{~S}_{24}$ & 7.50cde & 90000cde & 30403 & $59597 b c$ & $2.96 b$ \\
\hline $\mathrm{N}_{125} \mathrm{~K}_{125} \mathrm{~S}_{24}$ & $9.57 a b$ & 114840ab & 31653 & $83187 a b$ & $3.63 a b$ \\
\hline $\mathrm{N}_{125} \mathrm{~K}_{150} \mathrm{~S}_{24}$ & $10.30 a$ & $123600 a$ & 32278 & $91322 a$ & $3.83 a$ \\
\hline $\mathrm{N}_{125} \mathrm{~K}_{175} \mathrm{~S}_{24}$ & $10.33 a$ & $123960 a$ & 32903 & $91057 a$ & $3.77 a$ \\
\hline $\mathrm{N}_{125} \mathrm{~K}_{100} \mathrm{~S}_{0}$ & 7.90b-e & 94800b-e & 30218 & $64582 b c$ & $3.14 b$ \\
\hline $\mathrm{N}_{125} \mathrm{~K}_{100} \mathrm{~S}_{12}$ & $9.03 a b$ & 108360ab & 30623 & 77737ab & $3.54 a b$ \\
\hline $\mathrm{N}_{125} \mathrm{~K}_{100} \mathrm{~S}_{36}$ & $9.80 \mathrm{a}$ & $121200 a$ & 31433 & $89767 a$ & $3.86 a$ \\
\hline CV\% & 8.69 & 8.68 & -- & 10.26 & 9.87 \\
\hline Sig. & $\star *$ & $\star *$ & -- & * & * \\
\hline
\end{tabular}

Effect of potassium: Potassium significantly increased yield and yield attributes of onion. The maximum response of the crop to $\mathrm{K}$ fertilizer was observed in case of plant height, number of leaves/plant, single bulb weight and yield. The maximum plant height $(41.8 \mathrm{~cm})$, number of leaves (7.68/plant), length of bulb $(4.49 \mathrm{~cm})$, bulb diameter $(3.85 \mathrm{~cm})$ and weight of single bulb $(41.4 \mathrm{~g})$ was obtained from maximum (175 kg-K/ha) level of $\mathrm{K}$ application (Table 1). Potassium significantly increased yield and profitability of onion (Table 2). This result is supported by the reports that onions take up potassium (K) in quantities nearly equivalent to N (Pire et al., 2001; Singh and Verma, 2001; Salo et al., 


\section{S.N. Mozumder et al.}

2002). The maximum fresh bulb yield (10.33 t/ha) and GR (Tk. 1,23,960/ha) was obtained from $T_{11}$ treatment followed by $T_{10}(10.30 \mathrm{t} / \mathrm{ha}$, Tk. 1,23,600/ha). On the other hand, the net return (Tk. 91,322/ha) and benefit cost ratio (3.83) was maximum with $150 \mathrm{~kg}-\mathrm{K} / \mathrm{ha}$ than $\mathrm{T}_{11}$ (Tk. 91,057/ha and 3.77). Though the yield and GR was higher in $T_{11}$ treatment but net return and BCR was higher in $T_{10}$ than that of $T_{11}$ is due to the higher variable cost in $T_{11}(T k .32903 / h a)$ than $T_{10}(T k .32278 / h a)$. All these parameters were lower in the control treatment that supported by Singh and Verma, (2001) that if K is deficient or not supplied in adequate amounts, onion plants can be stunted, become susceptible to disease and have reduced yields. Because, the $\mathrm{K}$ requirement of onion plants increases with yield and its functions are linked to photosynthesis (Greenwood \& Stone, 1998). From the polynomial regression line (Fig. 2), the rate of yield increase was higher up to $150 \mathrm{~kg} \mathrm{~K} / \mathrm{ha}$ and become slow thereafter. From the polynomial regression analysis (Fig.3), K shows a strong positive correlation $(R=0.9793)$ between $\mathrm{S}$ application and bulb yield but it seems slight less than $\mathrm{N}$. The calculated optimum level of $\mathrm{K}$ for maximum yield is $183 \mathrm{~kg}$ $\mathrm{K}_{2} \mathrm{O} / \mathrm{ha}$ and the most economic rate of $\mathrm{K}$ was $174 \mathrm{~kg}-\mathrm{K}_{2} \mathrm{O} / \mathrm{ha}$. From fig. 4 and 5 it was observed that the number and weight loss of onion bulb during storage were not significantly differed among different $\mathrm{K}$ levels. The gradual deterioration of bulbs was observed up to October and it was rapid from October and onward. After February almost all the bulbs become dried and unfit for consumption.

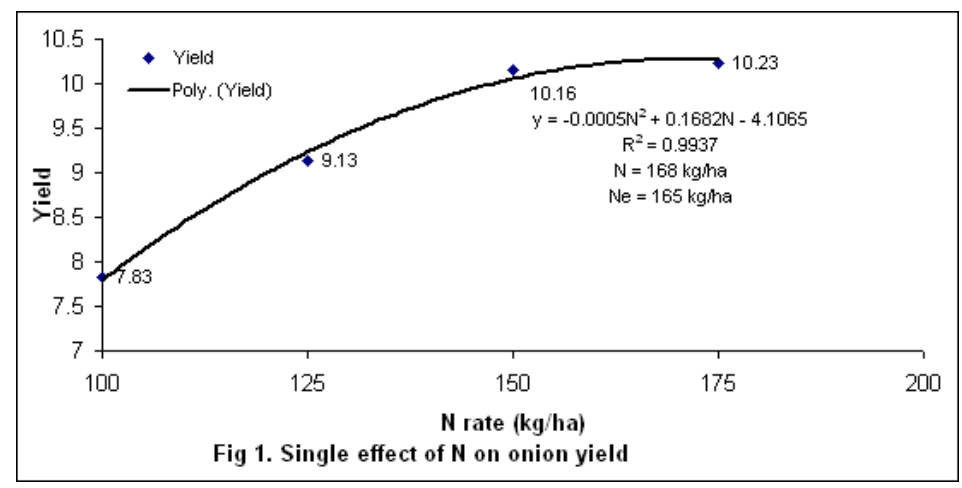

Effect of sulphur: Plant height, number of leaves/plant, length and diameter of bulb, single bulb weight, yield and profitability were significantly increased with the increased application of sulphur up to the maximum levels (36 kg-S/ha) (Table 1 and 2\}. The maximum plant height $(38.6 \mathrm{~cm})$, number of leaves $(7.60 /$ plant), bulb length $(4.17 \mathrm{~cm})$, diameter of bulb $(3.82 \mathrm{~cm})$, single bulb weight $(40.3 \mathrm{~g})$ and bulb yield $(9.80 \mathrm{t} / \mathrm{ha})$ were obtained from the highest level $(36 \mathrm{~kg})$ of sulphur. The higher GR (Tk.1,21,200/ha), NR (Tk.89,767/ha)and BCR (3.86) was obtained from same treatment $\left(T_{14}\right)$. From the polynomial regression analysis (Fig.3), Sulphur shows a positive correlation $(\mathrm{R}=0.9313)$ between $\mathrm{S}$ application and bulb yield but it seems slight weaker than $\mathrm{N}$ and $\mathrm{K}$. The calculated optimum level of $S$ from the regression curve for yield is $48 \mathrm{~kg}-\mathrm{S} / \mathrm{ha}$ and the most economic level is $30 \mathrm{~kg}-\mathrm{S} / \mathrm{ha}$. The overall condition of bulb showed similar trend of weight loss during storage time and also number of rotten bulbs with different S levels (Fig 4\&5).

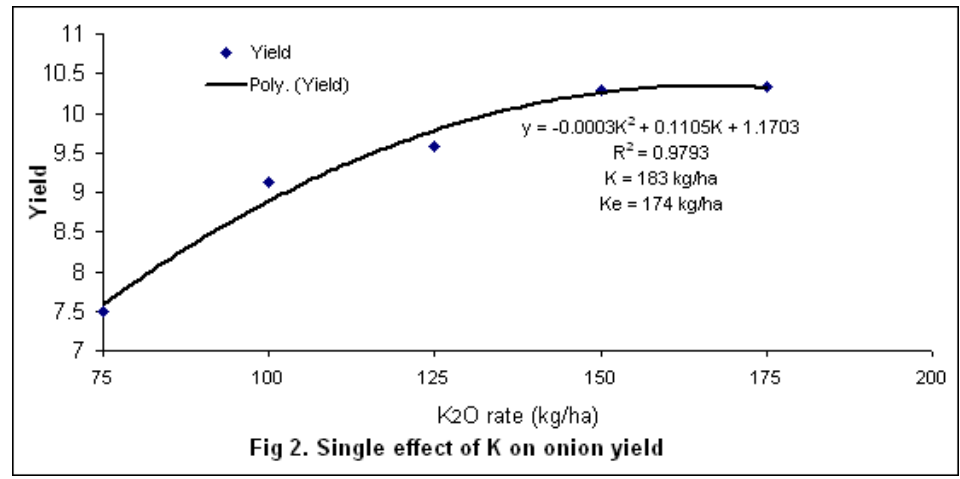


From this investigation it appeared that the response of crop to $\mathrm{N}, \mathrm{K}$ and $\mathrm{S}$ application was fairly with respect to the total production of onion in the hilly region. It was observed that the control treatment $\left(T_{1}\right)$ gave a reasonable bulb yield $(5.23 \mathrm{t} / \mathrm{ha})$ because there was a general dose $(10 \mathrm{t} / \mathrm{ha})$ of organic manure application. Additional chemical fertilizer of $\mathrm{N}, \mathrm{K}$ and $\mathrm{S}$ enhanced the crop growth, yield and profitability. It was evident that onion can successfully and profitably cultivated by seedling transplanting system applying $165 \mathrm{~kg} \mathrm{~N}, 174 \mathrm{~kg} \mathrm{~K}{ }_{2} \mathrm{O}$ and $30 \mathrm{~kg} \mathrm{~S}$ along with $10 \mathrm{t} / \mathrm{ha}$ cowdung and $75 \mathrm{~kg} \mathrm{P}_{2} \mathrm{O}_{5}$ in the eastern hilly areas of Bangladesh. It also observed that onion can be stored in the ambient temperature in well aerated tray up to October without or minimum weight loss. After October the bulbs started to sprout, outer scales become dry and rapidly loss its weight but can survive up to February in the normal room temperature. Kopsell-and Randle (1997) reported that the common phenomenon in storage of onion is percentage loss in mass and loss of dormancy. After February the bulbs become totally dry and sprouts were died because there was no additional nutrient or water for surviving the newly emerged shoots.
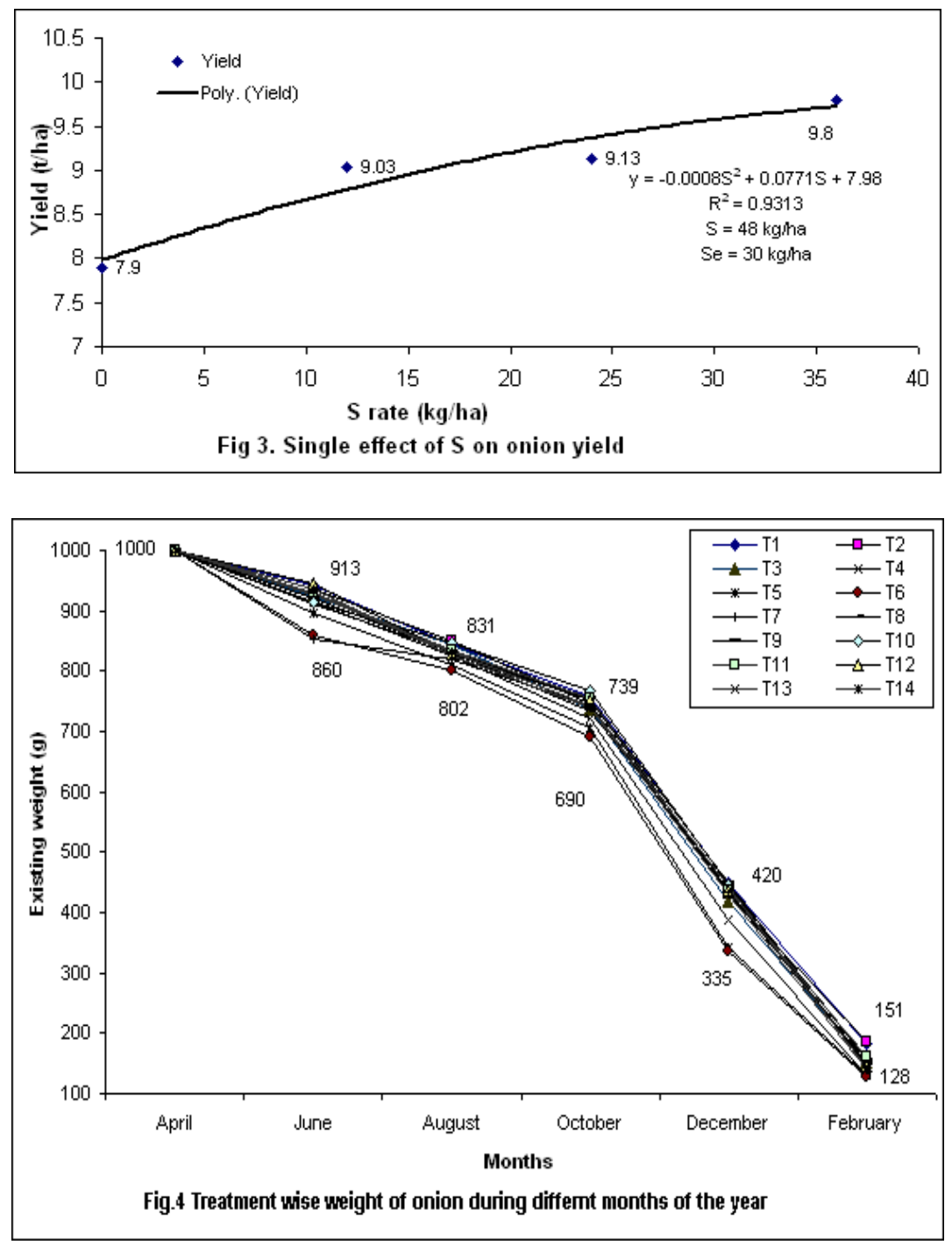


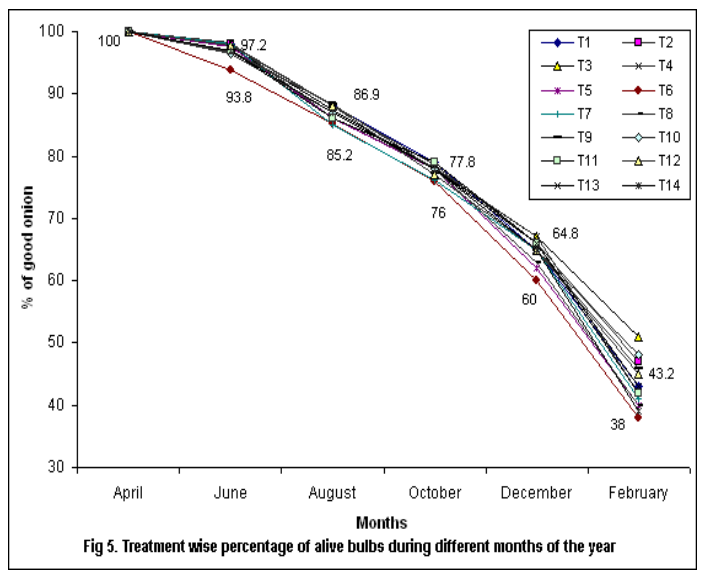

\section{CONCLUSION}

From this investigation, it appeared that transplanted onion production in the hilly areas is profitable and possible. The best fertilizer combination is $\mathrm{N}_{125} \mathrm{~K}_{150} \mathrm{~S}_{24}$ for higher yield and profitability in onion cultivation. Onion can be stored up to October without much weight loss in ambient temperature on well aerated bamboo mancha. After October, the weight loss are hastened and quality deteriorated rapidly.

\section{LITERATURE CITED}

Anonymous. 1969. International Soil Fertility Evaluation and Improvement Program. Technical Bulletin No. 5. North Carolina State University, USA.

Anonymous. 2000. Krishi Projukti Hatboi (Handbook of Agro Technology). $2^{\text {nd }}$ Edition. Bngladesh Agricultural Research Institute, Gazipur 1701, Bangladesh. pp. 376-81.

Anonymous. 2005. Onion seed production, probable loss and control measures (in Bengali). BARI Publication No. bklt-02 /2005-06.

Batal, K. M., Bondari, K Granberry D. M. and Mullinix, B.G. 1994. Effects of source, rate, and frequency of N application on yield, marketable grades and rot incidence of sweet onion (Allium cepa L. cv. Granex-33). Journal of Horticultural Science 69, 1043-1051.

Bose T. K. and Som, M. G. 1986. Onion. Cited in the Vegetable Crops in India. Naya Prakash. 206 Bidhan Sarani, Calcutta 700006. India. p. 728.

Brady, N. C. 1985. The Nature and Properties of Soils, 9th Ed ${ }^{\mathrm{n}}$., New Delhi.

Brewster, J. L. 1994. Onion and Other Vegetable Alliums. CAB International, UK.14(3), 1-3.

Greenwood, D. J. and Stone. D. A. 1998. Prediction and measurement of the decline in the critical-K, the maximum K and total plant cation concentration during the growth of field vegetable crops. Annals of Botany. 82, 871-881.

Kopsell, D. E. and Randle. W. M. 1997. Onion cultivars differ in pungency and bulb quality changes during storage. HortScience. USA. 32(7), 1260-1263.

Marschner, H. 1995. Mineral Nutrition of Higher Plants. 2nd Ed. Academic Press, London.

Pire, R., Ramirez, Riera, H., J. and Gómez. T.N. de 2001. Removal of N, P, K and Ca by an onion crop (Allium cepa L.) in a silty-clay soil, in a semiarid region of Venezuela. Acta Horticulturae 555, 103-109.

Salo, T., Suojala, T. and Kallela, M. 2002. The effect of fertigation on yield and nutrient uptake of cabbage, carrot and onion. Acta Horticulturae 571, 235-241.

Singh, J. and Dankhar, B. S. 1991. Effect of nitrogen, potash and zinc on storage loss of onion bulbs (Allium cepa L.). Vegetable Science 18, 16-23.

Singh, S. P. and Verma, A. B. 2001. Response of onion (Allium cepa) to potassium application. Indian Journal of Agronomy 46, 182-185.

Vachhani, M. U. and Patel, Z. G. 1993. Effect of nitrogen, phosphorus and potash on bulb yield and quality of onion (Allium cepa). Indian Journal of Agronomy 38, 333-334.

Woldetsadik, K. 2003. Shallot (Allium cepa var. ascolonicum) Responses to Plant Nutrients and Soil Moisture in a Subhumid Tropical Climate. Doctoral thesis. Department of Crop Science. Swedish University of Agricultural Sciences.

Zaman, S. M. H., Rahim, K. and Hawlader, M. 1982. Simple Lesson from Biometry, Bangladesh Rice Research Institute, Gzipur. pp 29-34. 